\title{
Chronic Antipsychotic Drug Treatment Induces Long-lasting Expression of fos and jun Family Genes and Activator Protein 1 Complex in the Rat Prefrontal Cortex
}

\author{
Outi Kontkanen, M.Sc., Merja Lakso, Ph.D., Garry Wong, Ph.D., and Eero Castrén, M.D.
}

We have characterized the effects of chronic clozapine and haloperidol treatments on the expression of fos (c-fos, fosB, fra-2) and jun (c-jun, junB, junD) family genes in the rat forebrain. The effects of chronic (17d) clozapine and haloperidol on $m R N A$ expression were determined two hours, 24 hours, and six days after the last drug injection, and the DNA-binding activity of the activator protein-1 (AP-1) complex was studied after washout periods of 24 hours and six days. Chronic clozapine treatment with a $6 \mathrm{~d}$ washout period induced the expression of several fos and jun family genes in cortical regions, including the prefrontal cortex (PFC), and in the caudate putamen and nucleus accumbens. Moreover, the DNA-binding activity of the AP-1 complex was greatly increased in the anterior cingulate cortex-PFC in mobility shift assays already after $24 h$, and remained increased after a $6 d$ washout period. Chronic administration of haloperidol upregulated fos and jun family mRNA expression that was detectable $24 \mathrm{~h}$ and $6 \mathrm{~d}$ after cessation of the treatment mainly in the cortex. However, the DNA-binding activity of the AP-1 complex was not altered in the anterior cingulate cortexPFC by chronic haloperidol administration at any of the time points studied. Thus, chronic treatments with clozapine and haloperidol induce a long-lasting enhancement of fos and jun family transcription factors that continues for several days after the cessation of the treatments in the cortex. These lasting effects might represent events that are potentially involved in the mechanisms of antipsychotic drug action.

[Neuropsychopharmacology 27:152-162, 2002] (C) 2002 American College of Neuropsychopharmacology. Published by Elsevier Science Inc.
KEY WORDS: Schizophrenia; Clozapine, Haloperidol; Transcription factors; In situ hybridization

From the A.I. Virtanen Institute (OK, ML, GW, EC), and Department of Psychiatry (EC), University of Kuopio, Kuopio, Finland.

Address correspondence to: Eero Castrén, A.I. Virtanen Institute, University of Kuopio, P.O. Box 1627 70211, Kuopio, Finland. Tel.: +358-17-162 084, fax: +358-17-163 030, E-mail: eero.castren@uku.fi

Received August 20, 2001; revised January 9, 2002; accepted January 16, 2002

Online publication: $1 / 17 / 02$ at www.acnp.org/citations/ Npp011702227.
Antipsychotic drugs increase the expression of immediate early gene protein c-Fos (Dragunow et al. 1990; Miller 1990; Nguyen et al. 1992), which is considered a marker of neuronal activation (Sagar et al. 1988; Dragunow and Faull 1989; Morgan and Curran 1991). Both acute haloperidol and clozapine treatments induce c-Fos in the shell compartment of the nucleus accumbens (AcbSh) and in the lateral septal nucleus, whereas haloperidol induces c-Fos also in the core of the nucleus accumbens (AcbC) and in the dorsal striatum (Dragunow et al. 1990; Miller 1990; Nguyen et al. 1992; Robertson and Fibiger 1992; Merchant and Dorsa 1993). Activation of striatal c-Fos by typical (including haloperidol), but 
not by atypical antipsychotics (including clozapine), has been hypothesized to result from the blockade of $D_{2}$ receptors by typical antipsychotic drugs and thus to reflect the manifestation of extrapyramidal side effects (Robertson et al. 1994). Unlike haloperidol, clozapine characteristically induces c-Fos in the prefrontal cortex (PFC), and this region has been proposed as a site underlying the unique effects of clozapine treatment (Robertson and Fibiger 1992; Fink-Jensen and Kristensen 1994; Robertson et al. 1994; Sebens et al. 1995; Deutch and Duman 1996; Kinon and Lieberman 1996).

Although the blockade of dopamine receptors by most antipsychotics takes place immediately after drug administration, the clinical antipsychotic effect develops slowly over the first days and weeks of treatment. The mechanisms behind the delayed drug effectiveness are unknown, but receptor-mediated transcriptional changes ultimately leading to alleviation of psychotic symptoms may occur. Alterations in neuronal activation following chronic, rather than acute antipsychotic drug treatment, may model the long-term drug effects in clinical use. However, only a few studies characterizing the outcome of chronic antipsychotic drug treatment on c-Fos expression have been undertaken. Chronic administration of haloperidol produces a c-Fos expression pattern essentially similar to that induced by acute treatment, but the induction is diminished especially in the striatum and nucleus accumbens (Sebens et al. 1995; Sun et al. 1998). Long-term haloperidol treatment also increases c-Fos in the limbic cortex such as in the anterior cingulate and entorhinal cortices, but not in the PFC (Merchant et al. 1996; Sun et al. 1998). Likewise, chronic treatment with clozapine induces a c-Fos expression pattern that is similar to acute clozapine treatment, but the induction is attenuated in many areas, except the nucleus accumbens (Sebens et al. 1995, 2000; Merchant et al. 1996).

Activator protein 1 (AP-1) complexes are formed by heterodimers between members of the Fos family (c-Fos, FosB, Fra-1 and Fra-2) and the Jun family (c-Jun, JunB and JunD) proteins, or by Jun protein homodimers. AP-1 complexes bind with high affinity to AP-1 DNA consensus sequence sites in regulatory regions of Fosinducible genes. Binding of the AP-1 complex usually activates the transcriptional activity of the target gene but, depending on the types of Fos and Jun proteins in the AP-1 complex, may also repress it (Herdegen and Leah 1998). Dopamine receptor antagonists are able to modulate the protein combination in the AP-1 complex. Acute administration of $\mathrm{D}_{2}$ antagonists haloperidol and $(-)$-sulpiride induces the expression of c-Fos, FosB, Fra$1, \mathrm{c}$-Jun and JunD proteins, whereas treatment with acute $\mathrm{SCH} 23390$, a $\mathrm{D}_{1}$ selective antagonist, results in upregulation of FosB, Fra-1 and JunD proteins (Ozaki et al. 1997, 1998). Acute and chronic haloperidol treatments increase the DNA-binding activity of the AP-1 complex in the rodent caudate putamen and whole brain extracts (Nguyen et al. 1992; Ozaki et al. 1997, 1998; Atkins et al. 1999), while the effects of clozapine on AP-1 complex binding activity remain more obscure.

A characteristic property of the fos and jun family genes is their rapid induction and downregulation (Herdegen and Leah 1998). Following activation, the mRNA levels of the immediate early genes usually decay within one hour, and the amounts of the corresponding proteins peak after one hour and decay within three to four hours (Herdegen and Leah 1998). These fast kinetics can also occur in the presence of continuous stimulation. Some stimuli are able to induce secondary waves of immediate early gene expression; however, even the secondary expression waves are typically gone by $12-24 \mathrm{~h}$ (Herdegen and Leah 1998).

Recently, fos family transcription factors have been classified into three categories: c-Fos, 'acute' Fra's, and 'chronic' Fra's (Nestler et al. 1999). As compared with rapid induction of c-Fos, 'acute' Fra's (e.g., FosB, $\Delta$ FosB, Fra-1, Fra-2) are induced somewhat later and their expression lasts longer than that of c-Fos. The 'chronic' Fra's, expressed after repeated inducing stimuli, are biochemically modified forms of $\Delta$ FosB protein, which have a very long life-span (Nestler et al. 1999). They are induced after chronic perturbations such as seizure, axotomy or transplantation, and following repeated exposure to neuroactive agents, such as cocaine, kainic acid, and antipsychotic drugs (Hope et al. 1994; Nye et al. 1995; Bing et al. 1996; Doucet et al. 1996; Herdegen and Leah 1998; Atkins et al. 1999; Kelz et al. 1999; Nestler et al. 1999; Morris et al. 2000).

We have here carried out an in situ hybridization examination of the expression of fos and jun family genes in several cortical and subcortical regions following chronic treatment by clozapine and haloperidol. We have also studied the functional activity of the AP- 1 complex after the drug treatments in the anterior cingulate cortex-PFC. The differential and long-lasting regulation of Fos and Jun family mRNAs in the limbic system by clozapine and haloperidol suggests a wider range of antipsychotic drug effects on brain than previously reported.

\section{MATERIALS AND METHODS}

\section{Animal Care and Drug Administration}

All animal experiments were performed in accordance to the guidelines of the Society for Neuroscience and were accepted by the experimental animal ethics committee of the University of Kuopio. Male Wistar rats ( $200 \mathrm{~g}$, National Laboratory Animal Center, University of Kuopio, Kuopio, Finland) were kept under standardized temperature, humidity and lighting conditions with free access to food and water. Animals were handled briefly during two days prior to the experi- 
ments. Each treatment group consisted of five to six animals. Rats were injected intraperitoneally either with saline $(1 \mathrm{ml} / \mathrm{kg}$, control), haloperidol $(1 \mathrm{mg} / \mathrm{kg}$, Serenase, Orion, Finland, diluted in saline) or clozapine (25 $\mathrm{mg} / \mathrm{kg}$, Leponex, Wander Pharma, Novartis Pharma $\mathrm{GmbH}$, Nürnberg, Germany), and sacrificed after the treatment period by decapitation under $\mathrm{CO}_{2}$ anesthesia. Chronic treatments were performed by daily injections for 17 days. The last injection of each treatment or saline was given two hours (17d 2hw), $24 \mathrm{~h}$ (17d 24hw), or six days $(17 \mathrm{~d} 6 \mathrm{dw}$ ) before sacrifice. For in situ hybridization, saline treated control animals were injected and matched separately for each drug treatment group to ensure identical handling. All control animals for electromobility shift assay experiments were injected with saline for $17 \mathrm{~d}$ and were allowed a $24-\mathrm{h}$ washout period.

\section{In situ Hybridization Procedure and Quantitation}

For in situ hybridization, the brains were collected after appropriate treatment periods, frozen on dry ice, and stored at $-75^{\circ} \mathrm{C}$ prior to cutting into $14 \mu \mathrm{m}$ thick sections in coronal orientation with a cryostat. Sections were mounted onto Superfrost slides (Fisher Scientific, Toronto, ON, Canada), postfixed in $4 \%$ paraformaldehyde, dehydrated, and stored under ethanol at $+4^{\circ} \mathrm{C}$ until used. The sections were hybridized with oligonucleotide probes that had been labeled with $\left[\alpha^{33} \mathrm{P}\right] \mathrm{dATP}$ by terminal deoxynucleotidyl transferase (MBI Fermentas, Vilnius, Lithuania). The antisense oligonucleotides recognizing rat c-Fos, FosB, c-Jun, JunB (Koistinaho et al. 1993), Fra-2 (nt 421-456, GenBank accession number U18913), and JunD (nt 890-924, GenBank accession number 450471) mRNAs were designed to minimize nonspecific hybridization. Hybridization was performed with 1-3 $\times 10^{3} \mathrm{cpm} / \mu 1$ of labeled probe in buffer containing 50\% formamide, $10 \%$ dextran sulfate and $4 \times$ SSC at $+42^{\circ} \mathrm{C}$ overnight. After incubation the sections were dipped into $1 \times$ SSC at room temperature, washed for $30 \mathrm{~min}$ at $+55^{\circ} \mathrm{C}$ in $1 \times \mathrm{SSC}$, washed sequentially for 3 min each at room temperature in $1 \times$ SSC, $0.1 \times$ SSC, $70 \%$ ethanol, and finally for $5 \mathrm{~min}$ in $94 \%$ ethanol. Sections were opposed onto Hyperfilm- $\beta$ max films (Amersham, Buckinghamshire, England) for 1-3 weeks and developed for 5 min in D-19 (Kodak, Rochester, NY).

Hybridized sections were quantified with $\mathrm{MCID}^{\mathrm{TM}}$ image analysis software (Imaging Research Inc., St. Catharines, Ontario, Canada) and optical densities were converted to specific binding using ${ }^{14} \mathrm{C}$ scaling. As the mRNA expression levels were quantified, it was not consistently possible to distinguish layer-specific expression patterns due to homogeneous expression of some of the fos and jun family genes. Therefore, the cortical layers were divided in superficial and deep layers. Quantitated brain regions were as follows: superficial and deep layers of the prefrontal cortex (PFC outer and inner, respectively) consisting of the cingulate cortex regions 1 and 3 (Cg1 and Cg3), and medial orbital cortex/ infralimbic cortex (IL) were all quantitated from sections cut within the distance of $+3.20-+4.20 \mathrm{~mm}$ from the bregma (see Figures 6-8 in Paxinos and Watson 1986). Superficial and deep layers of the anterior cingulate cortex (Cg outer and inner, respectively) consisting of the cingulate cortex regions 1 and $2(\mathrm{Cg} 1$ and $\mathrm{Cg} 2)$, the superficial layers of the frontal cortex (Fr1 and Fr2), the caudate putamen $(\mathrm{CPu})$, and the core $(\mathrm{AcbC})$ and shell (AcbSh) compartments of the nucleus accumbens were all quantified from sections cut within the distance of $+0.70-+1.60 \mathrm{~mm}$ from the bregma (see Figures 12-15 in Paxinos and Watson 1986). The analyzed brain regions are schematically shown in Figure 1, panels A and B. Hybridization intensities were quantified from matching brain regions of drug treated and identically saline treated control sections. The data are mean values of the specific binding of all sections from the treatment group, and are presented as percentage of the mean specific binding of the corresponding control sections.

\section{Electromobility Shift Assay Procedure}

For electromobility shift assays, the forebrain region comprising the prefrontal and anterior cingulate cortex was dissected after washout periods of 24 hours and six days following the chronic drug treatments, rapidly frozen on dry ice, and stored at $-75^{\circ} \mathrm{C}$. Nuclear proteins were extracted from the tissues by homogenization into hypotonic buffer containing $10 \mathrm{mM}$ Hepes $(\mathrm{pH}$ 7.9 ), $1.5 \mathrm{mM} \mathrm{MgCl}, 10 \mathrm{mM} \mathrm{KCl}, 0.2 \mathrm{mM}$ (p-amidinophenyl)methanesulfonyl fluoride (PMSF), $1 \mathrm{mM}$ dithiotreitol (DTT), $1 \mu \mathrm{g} / \mathrm{ml}$ leupeptin and $1 \mu \mathrm{g} / \mathrm{ml}$ aprotinin. The homogenate was centrifuged for $15 \mathrm{~min}$ at $\sim 1500 \mathrm{~g}$ (4000 rpm) at $+4^{\circ} \mathrm{C}$ and resuspended in a mixture of low-salt buffer (20 mM Hepes (pH 7.9), 25\% glycerol, $1.5 \mathrm{mM} \mathrm{MgCl} 2,1.2 \mathrm{mM} \mathrm{KCl}, 0.2 \mathrm{mM}$ EDTA, $0.2 \mathrm{mM}$ PMSF, $1 \mathrm{mM}$ DTT, $1 \mu \mathrm{g} / \mathrm{ml}$ leupeptin and $1 \mu \mathrm{g} / \mathrm{ml}$ aprotinin) and high salt buffer (same as low-salt buffer but with $20 \mathrm{mM} \mathrm{KCl}$ ) in the ratio of 2:1. After $30 \mathrm{~min}$ incubation on ice the homogenate was centrifuged at $\sim 15000 \mathrm{~g}$ (13000 rpm) for $30 \mathrm{~min}$ at $+4^{\circ} \mathrm{C}$ and the nuclear proteins were collected and stored in $-75^{\circ} \mathrm{C}$.

Activator protein-1 (AP-1) specific oligonucleotide (Promega, Madison, WI) was labeled with $\left[\gamma^{32} \mathrm{P}\right] \mathrm{ATP}$ using T4 polynucleotide kinase (Promega). Five micrograms of nuclear protein extract isolated from the anterior cingulate cortex-PFC was combined with labeled AP-1 oligonucleotide in binding buffer containing $10 \mathrm{mM}$ Tris/ $\mathrm{HCl}$ (pH 7.5), $5 \%$ glycerol, $1 \mathrm{mM} \mathrm{MgCl} 2,50 \mathrm{mM}$ $\mathrm{NaCl}$ and $0.5 \mathrm{mM}$ EDTA. Poly dI/dC $(2 \mu \mathrm{g})$ was added to inhibit non-specific DNA binding (Amersham Pharmacia Biotech, Buckinghamshire, UK). For super-shift experiments, $2 \mu \mathrm{g}$ of antibodies raised against Fos fam- 


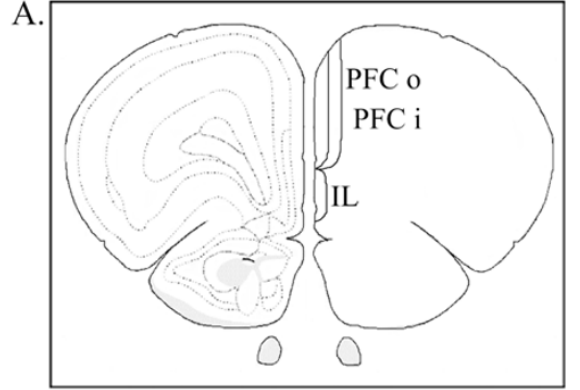

C.
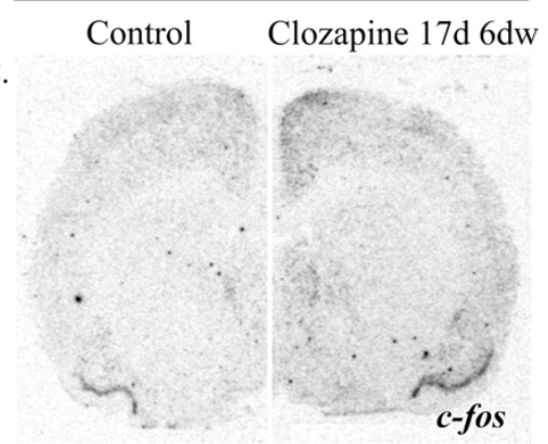

E.

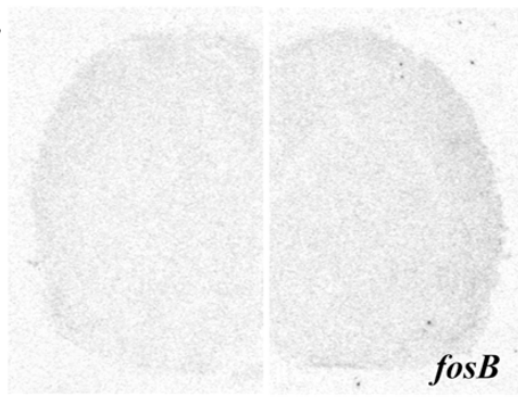

G.

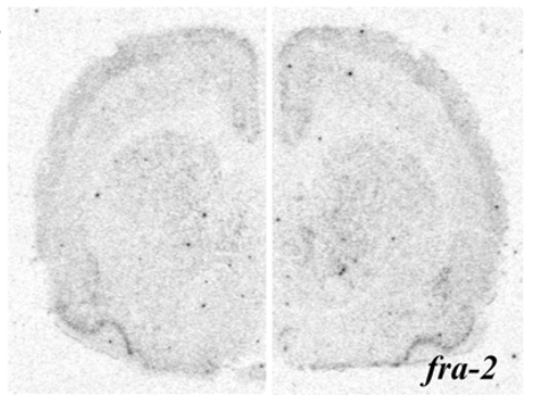

B.

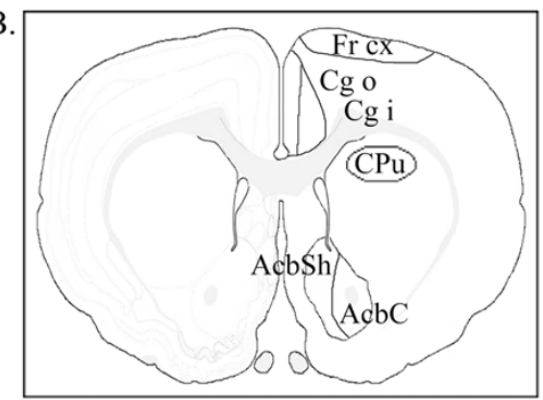

Control

D.

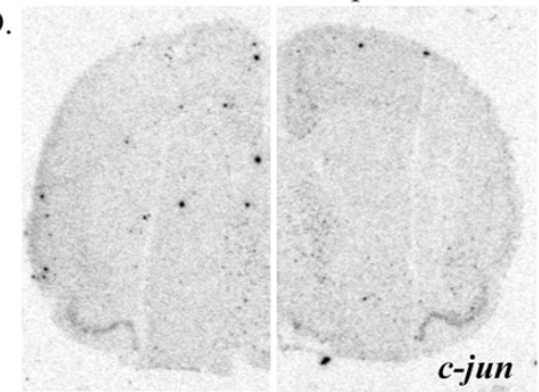

F.

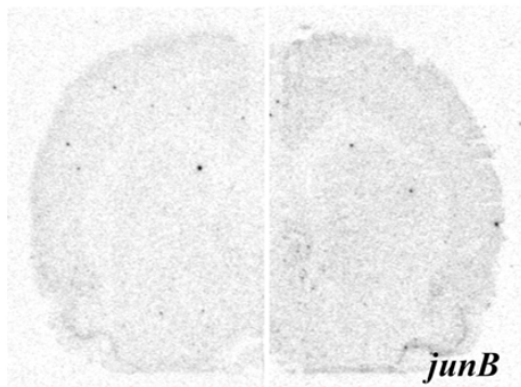

H.

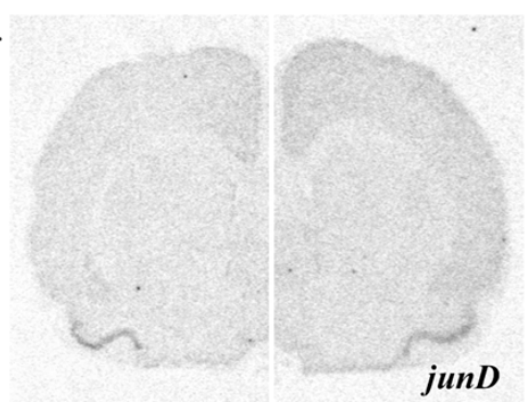

Figure 1. Expression patterns of the studied fos and jun family genes after chronic clozapine treatment followed by a 6 -d washout period $(17 \mathrm{~d}$ $6 \mathrm{dw})$. Schematic representation of the quantitated brain regions in in situ hybridization studies showing the regions of the (panel A) prefrontal (PFC) and infralimbic cortices (IL), and (panel B) frontal cortex (Fr cx), anterior cingulate cortex $(\mathrm{Cg} \mathrm{cx})$, caudate putamen $(\mathrm{CPu})$, and nucleus accumbens core (AcbC) and shell (AcbSh). Brain regions were quantitated at indicated levels or at their proximity (see Materials and Methods). Representative autoradiograms show mRNA expression of (panel C) $c$-fos, (panel E) fosB, (panel G) fra-2, (panel D) c-jun, (panel F) junB, and (panel $\mathrm{H}$ ) junD both in control (left panel) and clozapine (right panel) treated sections. ily proteins (recognizing c-Fos, FosB, Fra-1 and Fra-2, catalog number sc-253 X, Santa Cruz Biotechnology Inc., Santa Cruz, CA) or Jun family proteins (recognizing c-Jun, JunB and JunD, catalog number sc-44 X, Santa Cruz) was added to the nuclear protein extract prior to addition of labeled AP-1 oligonucleotide, and incubated for $2 \mathrm{~h}$ at $+4^{\circ} \mathrm{C}$ in a rotator. DNA-protein complexes were allowed to form for $20 \mathrm{~min}$ on ice and were resolved by $4 \%$ polyacrylamide gel electrophoresis at $100 \mathrm{~V}$ for $1.5 \mathrm{~h}$ in $1 \mathrm{x}$ Tris/glycine buffer, pH 8.5. The gels were then dried and exposed to X-ray films. DNA binding activity was quantitated with $\mathrm{MCID}^{\mathrm{TM}}$ image analysis software. Activities were converted to percents of AP-1 binding in comparison to protein extracts from saline treated animals.

\section{Data Analysis}

The results of in situ hybridization experiments were analyzed by ANOVA followed by post-hoc tests (twotailed Student's $t$-test). Electromobility shift assay results were analyzed by ANOVA followed by Dunnett's multiple comparison test.

\section{RESULTS}

We compared the effects of chronic treatment with clozapine and haloperidol on the expression levels of the fos (c-fos, fosB and fra-2) and jun (c-jun, junB and junD) family 
immediate early gene mRNAs in the rat forebrain using in situ hybridization. The drugs were administered for 17 days and washout periods of two hours, $24 \mathrm{~h}$, and six days were selected to further characterize the temporal expression patterns of fos and jun family genes. The functional activity of the AP-1 complex was measured in the anterior cingulate cortex-PFC after chronic drug treatment by electromobility shift assay. The effects on mRNA expression were dependent upon the drug administered and the duration following the last drug injection.

\section{Effects of Chronic Drug Treatment on fos and jun Family Gene Expression}

Quantified intensity values from in situ hybridized sections of all drug treatments, time points, studied genes, and brain regions were analyzed with ANOVA. A significant correlation was observed between the treatment groups (control and drug treated) and time points (17d 2hw, 17d 24hw, and $17 \mathrm{~d} 6 \mathrm{dw}$ ). The analysis indicated highly significant differences both for clozapine treated samples $(\mathrm{F}>8.9, \mathrm{df}=2, p<.0002)$, and for haloperidol treated samples $(\mathrm{F}>4.4, \mathrm{df}=2, p<.02)$. The data was further analyzed to identify the time points, genes and brain regions altered by the treatments.
Chronic clozapine treatment followed by a 2-h washout period downregulated the mRNA expression levels of $f o s B$ in the infralimbic cortex (Table 1), whereas the expression of $c-j u n$ was induced in the anterior cingulate cortex and in AcbSh (Table 2). No changes were detected in $c$-fos, fra-2, junB and junD mRNA expression at this time point.

Chronic haloperidol treatment followed by a $2-h$ withdrawal period downregulated the expression levels of $c$-fos (Table 1) and junB (Table 2) in the PFC. Moreover, junB expression was decreased in the anterior cingulate and infralimbic cortices, and in the AcbSh (Table 2). Levels of fosB, fra-2, c-jun and junD mRNA expression were not altered by chronic haloperidol treatment after a 2-h washout period.

After a 24-h washout period following chronic clozapine treatment, the expression of most fos and jun gene family mRNAs was unchanged. Only junB mRNA was upregulated in the PFC, especially in the deep cortical layers (Figure 2, panel D), and junD was downregulated in the anterior cingulate cortex (Table 2).

In contrast, chronic haloperidol treatment followed by a 24-h washout period induced the expression of $c$-fos in the frontal cortex, PFC, and in the anterior cingulate cortex, where the increase was most prominent

Table 1. Changes in the fos Family Gene mRNA Levels after Chronic Treatments

\begin{tabular}{|c|c|c|c|c|c|c|c|}
\hline \multirow[b]{2}{*}{ Gene } & \multirow[b]{2}{*}{ Region } & \multicolumn{3}{|c|}{ Clozapine } & \multicolumn{3}{|c|}{ Haloperiodol } \\
\hline & & $17 \mathrm{~d} 2 \mathrm{hw}$ & $17 \mathrm{~d} 24 \mathrm{hw}$ & $17 d 6 d w$ & 17d $2 \mathrm{hw}$ & $17 \mathrm{~d} 24 \mathrm{hw}$ & $17 \mathrm{~d} 6 \mathrm{dw}$ \\
\hline \multirow[t]{7}{*}{$c-f o s$} & Frontal cx & n.s. & n.s. & n.s. & n.s. & +++ & ++ \\
\hline & PFC & n.s. & n.s. & ++ & - & + & n.s. \\
\hline & $\mathrm{Cg} c \mathrm{x}$ & n.s. & n.s. & + & n.s. & ++ & n.s. \\
\hline & IL cx & n.s. & n.s. & + & n.s. & n.s. & n.s. \\
\hline & $\mathrm{CPu}$ & n.s. & n.s. & n.s. & n.s. & n.s. & n.s. \\
\hline & $\mathrm{AcbC}$ & n.s. & n.s. & ++ & n.s. & n.s. & n.s. \\
\hline & AcbSh & n.s. & n.s. & n.s. & n.s. & n.s. & n.s. \\
\hline \multirow[t]{7}{*}{$f \circ s B$} & Frontal cx & n.s. & n.s. & ++ & n.s. & n.s. & n.s. \\
\hline & PFC & n.s. & n.s. & n.s. & n.s. & n.s. & n.s. \\
\hline & $\mathrm{Cg} c \mathrm{x}$ & n.s. & n.s. & n.s. & n.s. & n.s. & n.s. \\
\hline & IL cx & -- & n.s. & n.s. & n.s. & n.s. & n.s. \\
\hline & $\mathrm{CPu}$ & n.s. & n.s. & n.s. & n.s. & n.s. & n.s. \\
\hline & AcbC & n.d. & n.d. & n.d. & n.d. & n.d. & n.d. \\
\hline & AcbSh & n.d. & n.d. & n.d. & n.d. & n.d. & n.d. \\
\hline \multirow[t]{7}{*}{ fra-2 } & Frontal cx & n.s. & n.s. & n.s. & n.s. & n.s. & n.s. \\
\hline & PFC & n.s. & n.s. & n.s. & n.s. & n.s. & n.s. \\
\hline & $\mathrm{Cgcx}$ & n.s. & n.s. & + & n.s. & n.s. & n.s. \\
\hline & IL cx & n.s. & n.s. & n.s. & n.s. & n.s. & n.s. \\
\hline & $\mathrm{CPu}$ & n.s. & n.s. & n.s. & n.s. & n.s. & n.s. \\
\hline & AcbC & n.s. & n.s. & n.s. & n.s. & n.s. & n.s. \\
\hline & AcbSh & n.s. & n.s. & n.s. & n.s. & n.s. & n.s. \\
\hline
\end{tabular}

Rats were injected with clozapine $(25 \mathrm{mg} / \mathrm{kg})$ or haloperidol $(1 \mathrm{mg} / \mathrm{kg})$ for $17 \mathrm{~d}$, and were sacrificed either $2 \mathrm{~h}(17 \mathrm{~d} 2 \mathrm{hw}), 24 \mathrm{~h}(17 \mathrm{~d} 24 \mathrm{hw})$ or $6 \mathrm{~d}(17 \mathrm{~d} 6 \mathrm{dw})$ after the last injection. mRNA expression levels were determined by in situ hybridization. Symbols: n.s., not significant; n.d., not determinable; + or - , increase or decrease, respectively, $p<.05 ;++$ or -- , increase or decrease, respectively, $p<.01 ;+++$, increase $p<.001$ (ANOVA followed by two-tailed Student's $t$-test). Abbreviations: Frontal cx $=$ frontal cortex, PFC $=$ prefrontal cortex, $\mathrm{Cg} \mathrm{cx}=$ cingulate cortex, $\mathrm{IL} \mathrm{cx}=$ infralimbic cortex, AcbC = nucleus accumbens core, and AcbSh $=$ nucleus accumbens shell. 
Table 2. Changes in the jun Family Gene mRNA Levels after Chronic Treatments

\begin{tabular}{|c|c|c|c|c|c|c|c|}
\hline \multirow[b]{2}{*}{ Gene } & \multirow[b]{2}{*}{ Region } & \multicolumn{3}{|c|}{ Clozapine } & \multicolumn{3}{|c|}{ Haloperiodol } \\
\hline & & 17d $2 \mathrm{hw}$ & 17d 24hw & $17 d 6 d w$ & 17d $2 \mathrm{hw}$ & $17 \mathrm{~d} 24 \mathrm{hw}$ & $17 d 6 d w$ \\
\hline \multirow[t]{7}{*}{$c-j u n$} & Frontal cx & n.s. & n.s. & + & n.s. & n.s. & ++ \\
\hline & PFC & n.s. & n.s. & n.s. & n.s. & n.s. & n.s. \\
\hline & $\mathrm{Cg} c x$ & + & n.s. & n.s. & n.s. & n.s. & ++ \\
\hline & IL cx & n.s. & n.s. & n.s. & n.s. & n.s. & n.s. \\
\hline & $\mathrm{CPu}$ & n.s. & n.s. & n.s. & n.s. & n.s. & ++ \\
\hline & AcbC & n.s. & n.s. & n.s. & n.s. & n.s. & n.s. \\
\hline & AcbSh & + & n.s. & ++ & n.s. & n.s. & n.s. \\
\hline \multirow[t]{7}{*}{ junB } & Frontal cx & n.s. & n.s. & n.s. & n.s. & n.s. & n.s. \\
\hline & PFC & n.s. & + & + & - & + & n.s. \\
\hline & $\mathrm{Cgcx}$ & n.s. & n.s. & ++ & - & n.s. & n.s. \\
\hline & IL cx & n.s. & n.s. & + & - & n.s. & n.s. \\
\hline & $\mathrm{CPu}$ & n.s. & n.s. & ++ & n.s. & n.s. & n.s. \\
\hline & AcbC & n.s. & n.s. & n.s. & n.s. & n.s. & n.s. \\
\hline & AcbSh & n.s. & n.s. & + & -- & n.s. & n.s. \\
\hline \multirow[t]{7}{*}{ junD } & Frontal cx & n.s. & n.s. & n.s. & n.s. & n.s. & n.s. \\
\hline & PFC & n.s. & n.s. & n.s. & n.s. & n.s. & n.s. \\
\hline & $\mathrm{Cgcx}$ & n.s. & - & n.s. & n.s. & n.s. & n.s. \\
\hline & IL cx & n.s. & n.s. & n.s. & n.s. & n.s. & n.s. \\
\hline & $\mathrm{CPu}$ & n.s. & n.s. & n.s. & n.s. & n.s. & n.s. \\
\hline & AcbC & n.s. & n.s. & n.s. & n.s. & n.d. & n.s. \\
\hline & AcbSh & n.s. & n.s. & n.s. & n.s. & n.d. & n.s. \\
\hline
\end{tabular}

Rats were injected with clozapine $(25 \mathrm{mg} / \mathrm{kg})$ or haloperidol $(1 \mathrm{mg} / \mathrm{kg})$ for $17 \mathrm{~d}$, and were sacrificed either $2 \mathrm{~h}(17 \mathrm{~d} 2 \mathrm{hw}), 24 \mathrm{~h}(17 \mathrm{~d} 24 \mathrm{hw})$ or $6 \mathrm{~d}(17 \mathrm{~d} 6 \mathrm{dw})$ after the last injection. mRNA expression levels were determined by in situ hybridization. Symbols: n.s., not significant; n.d., not determinable; + or - , increase or decrease, respectively, $p<.05 ;++$ or -- , increase or decrease, respectively, $p<.01 ;+++$, increase $p<.001$ (ANOVA followed by two-tailed Student's $t$-test). Abbreviations: Frontal $c x=$ frontal cortex, PFC $=$ prefrontal cortex, $\mathrm{Cg} c \mathrm{cx}=$ cingulate cortex, $\mathrm{IL} \mathrm{cx}=$ infralimbic cortex, $\mathrm{AcbC}=$ nucleus accumbens core, and $\mathrm{AcbSh}=$ nucleus accumbens shell.

in the deep cortical layers (Figure 3, panel A). In addition, the expression of $j u n B$ was increased in the PFC (Figure 3, panel D). Expression levels of fosB, c-jun and junD mRNAs were not significantly altered at $24 \mathrm{~h}$ after chronic haloperidol treatment.

At six days after the last clozapine injection the expression of $c-f o s, f o s B, c-j u n$ and junB mRNA levels were significantly upregulated. The induction of $c-f o s$ was the most pronounced in the PFC, especially in the superficial cortical layers (Figure 2, panel A), in the anterior cingulate cortex (Figure 1, panel C, and Figure 2, panel A), and in the infralimbic cortex (Table 1). Occasionally, an induction of $c$-fos mRNA was detected in the frontal cortex, but the induction did not reach statistical significance. In addition, $c$-fos was induced in the AcbC (Figure 1, panel C, and Table 1). The expression level of fos $B$ mRNA was very low throughout the brain. Yet, a modest but consistent increase of $\operatorname{fos} B$ transcript was observed in the frontal cortex after a 6-d washout period (Figure 1, panel E, and Figure 2, panel B). The mRNA expression of $c$-jun was also increased in the frontal cortex six days following the cessation of clozapine treatment (Figure 1, panel D, and Figure 2, panel C). Moreover, c-jun expression was upregulated in the AcbSh
(Figure 1, panel D, and Table 2). The mRNA levels of junB were generally induced and the upregulation was the most pronounced in the PFC (especially in the superficial layers) (Figure 2, panel D), and in the anterior cingulate cortex (Figure 1, panel F, and Figure 2, panel D). In addition, jun $B$ was induced in the infralimbic cortex (Table 2), in the caudate putamen and AcbSh (Figure 1, panel F, and Table 2). fra-2 (Figure 1, panel G) and junD (Figure 1, panel $\mathrm{H}$ ) mRNAs remained essentially at their basal expression levels in the quantitated regions.

Chronic haloperidol treatment followed by a $6-\mathrm{d}$ washout period led to activated transcription of $c-f o s$ and $c-j u n$ mRNAs predominantly in the cortical regions. In the frontal cortex, expression of both $c-f o s$ and $c-j u n$ mRNAs was significantly increased (Figure 3, panels A and C, respectively). Upregulation of $c$-jun expression was also detected in the anterior cingulate cortex (Figure 3, panel C), and in the caudate putamen (Table 2). At this time point, other genes studied were not significantly regulated from their basal levels.

In general, the magnitude of gene induction in the cortex by chronic antipsychotic drug treatments with variable washout periods was around the same level or less than that produced by acute drug treatments (un- 


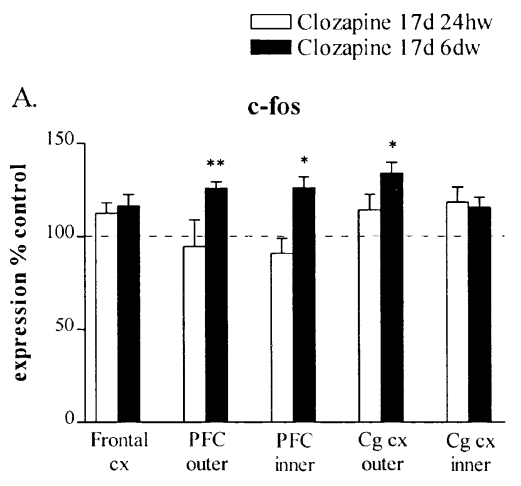

B.

fos B

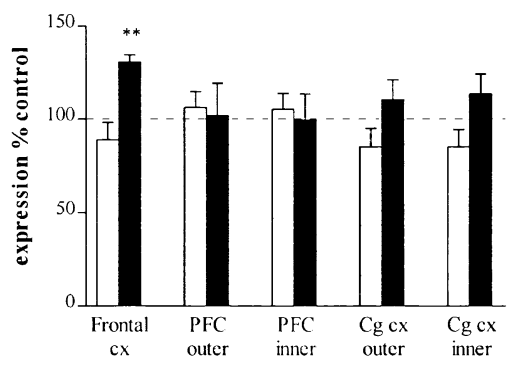

C.
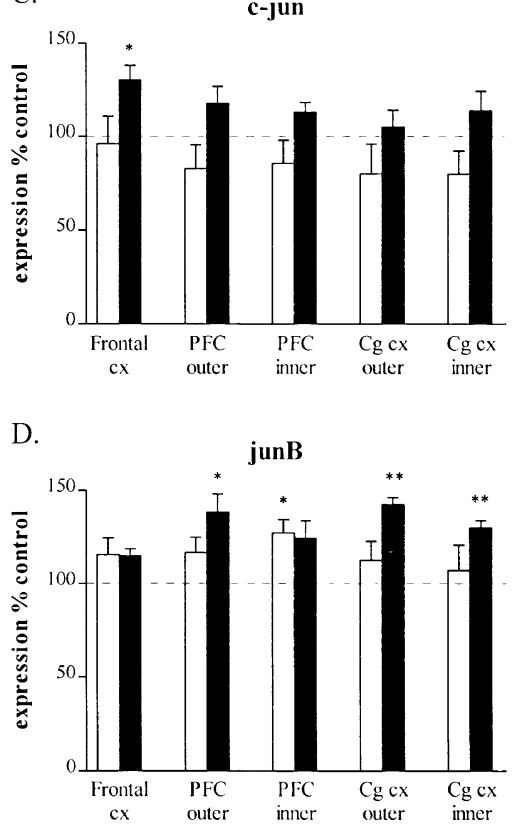

Figure 2. Effects of chronic (17 d) administration of clozapine $(25 \mathrm{mg} / \mathrm{kg})$ with different washout periods on the expression of (panel A) $c$-fos, (panel B) fosB, (panel C) $c$-jun, and (panel D) junB mRNA levels as studied with in situ hybridization. The expression levels were quantitated following $24-\mathrm{h}(17 \mathrm{~d} 24 \mathrm{hw})$ and $6-\mathrm{d}(17 \mathrm{~d} 6 \mathrm{dw})$ washout periods after the cessation of repeated clozapine treatment. ${ }^{*}, p<.05$; ${ }^{*}, p<.01$ as compared with respective control sections. Data are mean \pm SEM values $(n=5-6$, two-tailed Student's $t$-test $)$. PFC: prefrontal cortex; $\mathrm{Cg}$ cx: anterior cingulate cortex; outer: superficial layers; inner: deep layers (see Materials and Methods).
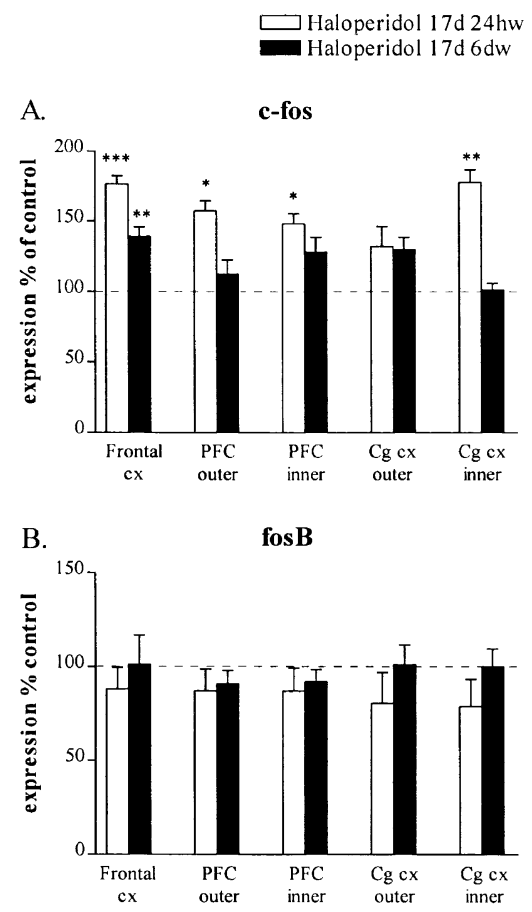

C. c-jun
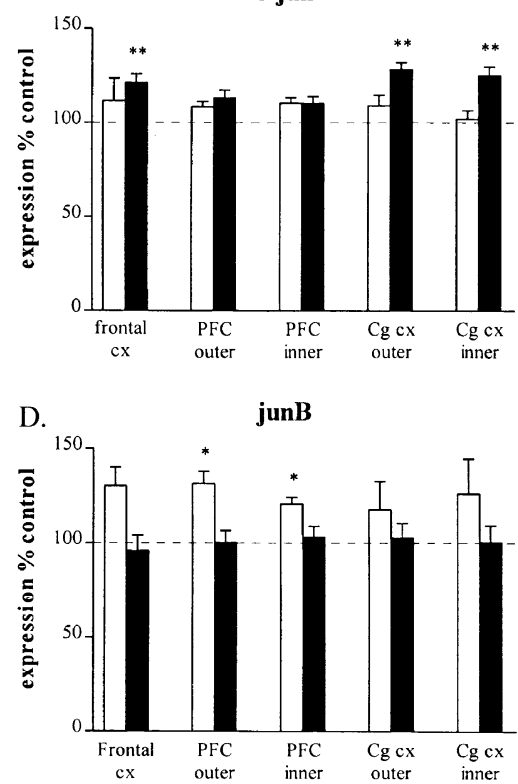

Figure 3. Effects of chronic $(17 \mathrm{~d})$ administration of haloperidol $(1 \mathrm{mg} / \mathrm{kg})$ with different washout periods on the expression of (panel A) c-fos, (panel B) fosB, (panel C) c-jun, and (panel D) junB mRNA levels as studied with in situ hybridization. The expression levels were quantitated following $24-\mathrm{h}$ (17d 24hw) and a 6-d (17d 6dw) washout periods after the cessation of haloperidol treatment. ${ }^{*}, p<.05$; ${ }^{* *}, p<.01 ;{ }^{* * *}, p<.001$ as compared with respective control sections. Data are mean \pm SEM values $(n=5-6$, Student's t-test). PFC: prefrontal cortex; $\mathrm{Cg}$ cx: anterior cingulate cortex; outer: superficial layers; inner: deep layers. 
published data, O.K. and E.C.). With haloperidol treatment, the induction of $c$-fos in the cortex with chronic treatment was, however, always less than the induction of $c-f o s$ in the striatum after acute treatment (unpublished data, O.K. and E.C.).

\section{Regulation of the DNA-binding Activity of the AP-1 Complex after Chronic Drug Treatment}

We next studied whether the induction of mRNAs for fos and jun gene family members by chronic drug treatments was accompanied with changes in the DNA binding activity of the AP- 1 complex in the anterior cingulate cortex-PFC. Chronic clozapine treatment followed by withdrawal periods of $24 \mathrm{~h}$ and six days greatly increased the DNA binding activity of the AP-1 complex as shown by electromobility shift assay (Figure 4, panel A). Quantitation revealed that the DNA binding activity of the AP-1 complex was increased about twofold at both time points studied as compared with saline treated (17d 24hw) control samples (Figure 4, panel B). The increased DNA binding activity of the AP-1 complex after chronic clozapine treatments was inhibited by the addition of Fos and Jun family protein antibodies in super-shift assays (Figure 4, panel C). Both after 24-h and 6-d washout periods, the DNA-protein complexes were shifted by Fos family antibody, whereas the addition of Jun family antibody decreased the DNA binding activity of the AP- 1 complex without producing a shift in the mobility of the complexes.

Next, we investigated the effect of chronic haloperidol treatment followed by $24-\mathrm{h}$ and $6-\mathrm{d}$ washout periods on the DNA binding activity of the AP-1 complex. In contrast to clozapine treatment, chronic administration of haloperidol did not result in altered DNA-binding activity of the AP-1 complex at any of the time points studied in the anterior cingulate cortex-PFC (data not shown).

\section{DISCUSSION}

Several studies have reported alterations in c-Fos expression as a marker of changes in transcriptional activity induced by acute antipsychotic drug treatment (Dragunow et al. 1990; Miller 1990; Nguyen et al. 1992; Robertson and Fibiger 1992; Merchant and Dorsa 1993; Fink-Jensen and Kristensen 1994; Sebens et al. 1995; Deutch and Duman 1996). However, only a few studies have characterized the outcome of chronic antipsychotic drug treatments on c-Fos expression (Sebens et al. 1995, 2000; Merchant et al. 1996; Sun et al. 1998). In addition to c-Fos, there are various other gene members of fos and jun families, which act as powerful regulators of gene expression. Most of the previous studies on c-Fos expression by antipsychotic drug treatments have em-

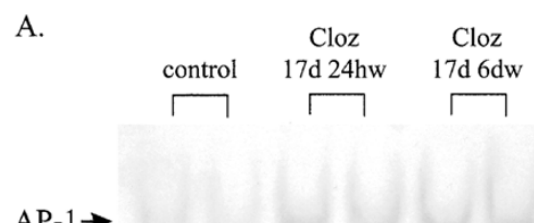

$\mathrm{AP}-1 \rightarrow$

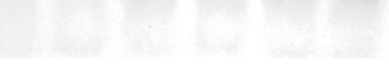

B.
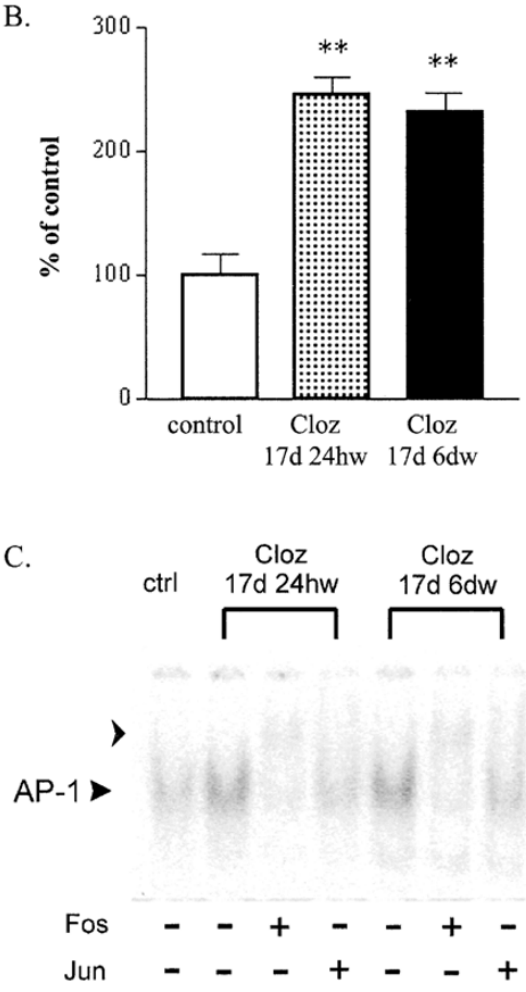

Figure 4. Induction of the DNA-binding activity of the AP-1 complex in the anterior cingulate cortex-PFC of rat brain in response to chronic $(17 \mathrm{~d})$ clozapine $(25 \mathrm{mg} / \mathrm{kg})$ treatment. A. Duplicate representatives of the gel shift assays show increased AP-1 binding after 24 hours (17d 24hw) and six days $(17 \mathrm{~d} 6 \mathrm{dw})$ of withdrawal following repeated clozapine administration. Control tissues were treated with saline for the period of $17 \mathrm{~d} 24 \mathrm{hw}$. B. Quantified results of the AP-1 binding activity as compared with saline treated control tissues $(\mathrm{n}=5-6)$. C. Addition of Fos and Jun protein antibodies inhibits the induced DNA-binding activity of the AP-1 complex in chronic clozapine treated samples. Fos antibody-shifted band is indicated with an arrowhead. ${ }^{* *}, p<.01$. Data are mean \pm SEM values (Dunnett's multiple comparison test).

ployed immuno-labeling techniques, while we have here characterized the changes in several fos (c-fos, fos- $B$, fra-2) and jun (c-jun, junB, junD) family gene members' mRNA expression levels using radioactive in situ hybridization. We have investigated alterations in mRNA levels in several potential target regions of chronic antipsychotic drug treatments. We also measured the DNA binding activity of the AP-1 complex formed by Fos and Jun family proteins in order to correlate the mRNA 
expression with the presence and function of the proteins. We describe here an unexpectedly long-lasting induction of $f o s$ and jun family genes in the rat forebrain following chronic treatment with clozapine and haloperidol.

\section{Effects of Chronic Clozapine Treatment}

The effect of chronic clozapine treatment on fos and jun family gene transcript expression was dependent on the washout period, since only minor regulation in limited brain areas was observed at two and $24 \mathrm{~h}$ after the last injection. This is in accordance with previous studies that have reported tolerance in the induction of Fos protein expression immediately after chronic clozapine treatment (Sebens et al. 1995, 2000; Merchant et al. 1996; Sun et al. 1998).

In contrast to the short washout periods, a marked induction of the fos and jun family gene mRNA levels was detected in several regions of the rat forebrain following a 6-d washout period after the cessation of chronic clozapine treatment. Induction of $c-f o s$ and junB was observed in cortical areas, as well as in the caudate putamen and nucleus accumbens. Moreover, the expression of $f_{o s} B$, fra-2 and c-jun was induced in more restricted regions. Increased expression of fos $B$ mRNA in the frontal cortex after chronic clozapine treatment is in line with recently reported increase in the FosB immunoreactivity after long chronic (six months) clozapine treatment (Rodriguez et al. 2001). Although we were able to detect limited changes in the expression of fos $B$ mRNA after chronic drug treatment, the possible role of $\Delta$ FosB isoforms in long-term clozapine effects cannot be excluded.

Interestingly, although only minor regulation of the transcripts was observed after a 24-h washout period, the DNA-binding activity of the AP-1 complex was strongly enhanced in the anterior cingulate cortex-PFC at this time point. The substantial induction in the AP-1 binding persisted following six days of drug-free period after chronic clozapine administration. Super-shift experiments revealed that the majority of the DNA-protein complexes after both washout periods involve Fos family proteins, as the DNA binding of the AP-1 complex was shifted by the addition of Fos family antibody. It appears that Jun family proteins are less abundant in the AP-1 complexes after chronic clozapine treatments since the AP-1 binding was reduced, but not shifted, with the addition of Jun family antibody. These data suggest that chronic clozapine treatment induces persistent transcription of a subset of fos and jun family genes, and concomitantly increases the functional activity of the Fos and Jun family proteins.

\section{Effects of Chronic Haloperidol Treatment}

Cessation of chronic haloperidol administration either had no effect on or reduced the mRNAs of fos and jun family genes at two hours after the last injection, but thereafter led to long-lasting induction that was observed after 24 hours and six days of drug-free period. The lack of fos and jun family mRNA upregulation after a 2-h washout period is consistent with previous reports that have showed tolerance in the inducibility of Fos protein expression immediately after chronic haloperidol treatment (Sebens et al. 1995, 2000; Merchant et al. 1996; Sun et al. 1998).

After $24 \mathrm{~h}$ washout period, the expression of $c-f o s$ was the most markedly induced in the frontal cortex, but we detected a minor increase in $c$-fos expression also in the PFC. Induced $c$-fos mRNA level in the PFC is not consistent with previously published expression pattern of c-Fos by chronic haloperidol treatment (Merchant et al. 1996; Sun et al. 1998). This discrepancy may be produced by differences in the studied time point and in the methodology of detection. Increase in $c$-fos expression was the most marked in the frontal cortex where the induction was still observed after a 6-d drug-free period. At this time point the transcript levels of $c$-jun were also induced in cortical regions and in the caudate putamen.

Despite of the induction in the fos and jun family transcript expression, the DNA-binding activity of the AP-1 complex was not altered by chronic haloperidol treatment in the anterior cingulate cortex-PFC at any of the time points investigated. Fos and Jun proteins are known to be capable of heterodimerizing with other transcription factors, and these heterodimers tend to shift the binding affinity from AP-1 sequence site to other DNA motifs (Herdegen and Leah 1998). This may explain our inability to detect changes in AP-1 binding affinity following chronic administration of haloperidol.

\section{Conclusions}

Repeated administration of clozapine and haloperidol may lead to drug accumulation in brain, and thus to result in altered gene expression several days after cessation of the treatment. Clozapine administered with i.p. injection has been reported to have a terminal half-life of 1.5-1.6 $\mathrm{h}$ in the rat brain, and it does not significantly accumulate in brain after a week of daily dosing (Baldessarini et al. 1993). Therefore, it is unlikely that significant amounts of clozapine are present in brain $24 \mathrm{~h}$ or later after the cessation of chronic treatment. Similarly, haloperidol has been described to have a terminal half-life of $1.5 \mathrm{~h}$ in rat (Cheng and Paalzow 1992), but longer half-lives have also been reported (Cohen et al. 1992). Consequently, residual amounts of haloperidol may still be present in brain after several days of drug withdrawal. However, because the most widespread and functionally significant changes were observed after chronic treatment with clozapine, it is unlikely that accumulation of drugs in brain can explain the extended induction and function of fos and jun family genes. 
Finally, long-term drug treatments, such as with cocaine, antidepressants and ethanol, are known to cause tolerance and dependence, and as the treatment is recessed, are accompanied with symptoms of drug withdrawal. Others, and we here, have also detected tolerance in the inducibility of immediate early gene expression immediately after chronic administration of antipsychotic drugs (Sebens et al. 1995, 2000). However, the initial tolerance in fos and jun family gene expression after the cessation of chronic antipsychotic drug treatments was followed here by a marked induction in the gene expression as the drug-free period progressed. Clinical studies have indicated certain cases of relapse of schizophrenic patients after long-term antipsychotic drug medication is withdrawn (Ekblom et al. 1984; Gilbert et al. 1995; Meltzer et al. 1996; Shiovitz et al. 1996). Moreover, the occurrence of relapse in patients withdrawn from clozapine treatment appears to be higher than that of neuroleptic-treated patients (Meltzer et al. 1996). It is possible, that the induction of fos and jun family genes one to six days after the cessation of the long-term clozapine and haloperidol treatments may be associated with drug withdrawal effect at the level of gene expression.

Taken together, our results indicate that chronic antipsychotic drug treatments may induce changes in target gene expression through actions of Fos and Jun transcription factors several days after the cessation of chronic antipsychotic drug administration. Experiments using DNA microarray technology might provide further information about the genes regulated by fos and jun family transcription factors in response to antipsychotic drug medication. This could advance the understanding of the molecular mechanisms of the action of antipsychotic drugs and help to design more selective drugs.

\section{ACKNOWLEDGMENTS}

We are grateful to Eija Koponen, Marketa Marvanova, and Markus Storvik for their support in animal experiments, to Pirjo Halonen for help with statistical analysis, and to Anne Lehtelä, Anne-Mari Friis, and Laila Kukkonen for their excellent technical assistance. We also thank Dr. Antero Salminen for help with EMSA assays and Dr. Jari Koistinaho for providing the oligonucleotide probes.

\section{REFERENCES}

Atkins JB, Chlan-Fourney J, Nye HE, Hiroi N, Carlezon WA, Nestler EJ (1999): Region-specific induction of deltaFosB by repeated administration of typical versus atypical antipsychotic drugs. Synapse 33:118-128

Baldessarini RJ, Centorrino F, Flood JG, Volpicelli SA, Huston-Lyons D, Cohen BM (1993): Tissue concentrations of clozapine and its metabolites in the rat. Neuropsychopharmacology 9:117-124
Bing G, McMillian M, Kim H, Pennypacker K, Feng Z, Qi Q, Kong LY, Iadarola M, Hong JS (1996): Long-term expression of the 35,000 mol. wt fos-related antigen in rat brain after kainic acid treatment. Neuroscience 73:11591174

Cheng YF, Paalzow LK (1992): Linear pharmacokinetics of haloperidol in the rat. Biopharm Drug Dispos 13:69-76

Cohen BM, Tsuneizumi T, Baldessarini RJ, Campbell A, Babb SM (1992): Differences between antipsychotic drugs in persistence of brain levels and behavioral effects. Psychopharmacology (Berl) 108:338-344

Deutch AY, Duman RS (1996): The effects of antipsychotic drugs on Fos protein expression in the prefrontal cortex: cellular localization and pharmacological characterization. Neuroscience 70:377-389

Doucet JP, Nakabeppu Y, Bedard PJ, Hope BT, Nestler EJ, Jasmin BJ, Chen JS, Iadarola MJ, St-Jean M, Wigle N, Blanchet P, Grondin R, Robertson GS (1996): Chronic alterations in dopaminergic neurotransmission produce a persistent elevation of deltaFosB-like protein(s) in both the rodent and primate striatum. Eur J Neurosci 8:365-381

Dragunow M, Faull R (1989): The use of c-fos as a metabolic marker in neuronal pathway tracing. J Neurosci Methods 29:261-265

Dragunow M, Robertson GS, Faull RL, Robertson HA, Jansen K (1990): D2 dopamine receptor antagonists induce fos and related proteins in rat striatal neurons. Neuroscience 37:287-294

Ekblom B, Eriksson K, Lindstrom LH (1984): Supersensitivity psychosis in schizophrenic patients after sudden clozapine withdrawal. Psychopharmacology (Berl) 83: 293-294

Fink-Jensen A, Kristensen P (1994): Effects of typical and atypical neuroleptics on Fos protein expression in the rat forebrain. Neurosci Lett 182:115-118

Gilbert PL, Harris MJ, McAdams LA, Jeste DV (1995): Neuroleptic withdrawal in schizophrenic patients. A review of the literature. Arch Gen Psychiatry 52:173-188

Herdegen T, Leah JD (1998): Inducible and constitutive transcription factors in the mammalian nervous system: control of gene expression by Jun, Fos and Krox, and CREB/ ATF proteins. Brain Res Brain Res Rev 28:370-490

Hope BT, Nye HE, Kelz MB, Self DW, Iadarola MJ, Nakabeppu Y, Duman RS, Nestler EJ (1994): Induction of a long-lasting AP-1 complex composed of altered Fos-like proteins in brain by chronic cocaine and other chronic treatments. Neuron 13:1235-1244

Kelz MB, Chen J, Carlezon WA, Whisler K, Gilden L, Beckmann AM, Steffen C, Zhang YJ, Marotti L, Self DW, Tkatch T, Baranauskas G, Surmeier DJ, Neve RL, Duman RS, Picciotto MR, Nestler EJ (1999): Expression of the transcription factor deltaFosB in the brain controls sensitivity to cocaine. Nature 401:272-276

Kinon BJ, Lieberman JA (1996): Mechanisms of action of atypical antipsychotic drugs: a critical analysis. Psychopharmacology (Berl) 124:2-34

Koistinaho J, Pelto-Huikko M, Sagar SM, Dagerlind A, Roivainen R, Hokfelt T (1993): Differential expression of immediate early genes in the superior cervical ganglion after nicotine treatment. Neuroscience 56:729-739

Meltzer HY, Lee MA, Ranjan R, Mason EA, Cola PA (1996): Relapse following clozapine withdrawal: effect of neu- 
roleptic drugs and cyproheptadine. Psychopharmacology (Berl) 124:176-187

Merchant KM, Dorsa DM (1993): Differential induction of neurotensin and c-fos gene expression by typical versus atypical antipsychotics. Proc Natl Acad Sci USA 90:3447-3451

Merchant KM, Figur LM, Evans DL (1996): Induction of c-fos mRNA in rat medial prefrontal cortex by antipsychotic drugs: role of dopamine D2 and D3 receptors. Cereb Cortex 6:561-570

Miller JC (1990): Induction of c-fos mRNA expression in rat striatum by neuroleptic drugs. J Neurochem 54:1453-1455

Morgan JI, Curran T (1991): Stimulus-transcription coupling in the nervous system: involvement of the inducible protooncogenes fos and jun. Annu Rev Neurosci 14:421-451

Morris TA, Jafari N, DeLorenzo RJ (2000): Chronic DeltaFosB expression and increased AP-1 transcription factor binding are associated with the long term plasticity changes in epilepsy. Brain Res Mol Brain Res 79: 138-149

Nestler EJ, Kelz MB, Chen J (1999): DeltaFosB: a molecular mediator of long-term neural and behavioral plasticity. Brain Res 835:10-17

Nguyen TV, Kosofsky BE, Birnbaum R, Cohen BM, Hyman SE (1992): Differential expression of c-fos and zif268 in rat striatum after haloperidol, clozapine, and amphetamine. Proc Natl Acad Sci USA 89:4270-4274

Nye HE, Hope BT, Kelz MB, Iadarola M, Nestler EJ (1995): Pharmacological studies of the regulation of chronic FOSrelated antigen induction by cocaine in the striatum and nucleus accumbens. J Pharmacol Exp Ther 275:1671-1680

Ozaki T, Katsumoto E, Mui K, Furutsuka D, Yamagami S (1998): Distribution of Fos- and Jun-related proteins and activator protein-1 composite factors in mouse brain induced by neuroleptics. Neuroscience 84:1187-1196

Ozaki T, Katsumoto E, Yokotani N, Yamagami S (1997): The comparative effects of haloperidol, (-)-sulpiride, and SCH23390 on c-fos and c-jun mRNA expressions, and AP-1 DNA binding activity. Eur Neuropsychopharmacol 7:181-187

Paxinos G, Watson C (1986): The Rat Brain in Stereotaxic Coordinates. 2nd ed. Sydney, Academic Press

Robertson GS, Fibiger HC (1992): Neuroleptics increase c-fos expression in the forebrain: contrasting effects of haloperidol and clozapine. Neuroscience 46:315-328

Robertson GS, Matsumura H, Fibiger HC (1994): Induction patterns of Fos-like immunoreactivity in the forebrain as predictors of atypical antipsychotic activity. J Pharmacol Exp Ther 271:1058-1066

Rodriguez JJ, Garcia DR, Nakabeppu Y, Pickel VM (2001): Enhancement of Laminar FosB Expression in Frontal Cortex of Rats Receiving Long Chronic Clozapine Administration. Exp Neurol 168:392-401

Sagar SM, Sharp FR, Curran T (1988): Expression of c-fos protein in brain: metabolic mapping at the cellular level. Science 240:1328-1331

Sebens JB, Koch T, Ter Horst GJ, Korf J (1995): Differential Fos-protein induction in rat forebrain regions after acute and long-term haloperidol and clozapine treatment. Eur J Pharmacol 273:175-182

Sebens JB, Kuipers SD, Koch T, Ter Horst GJ, Korf J (2000): Limited participation of 5-HT(1A) and 5-HT(2A/2C) receptors in the clozapine-induced Fos-protein expression in rat forebrain regions. Eur J Pharmacol 408:11-17

Shiovitz TM, Welke TL, Tigel PD, Anand R, Hartman RD, Sramek JJ, Kurtz NM, Cutler NR (1996): Cholinergic rebound and rapid onset psychosis following abrupt clozapine withdrawal. Schizophr Bull 22:591-595

Sun YJ, Suzuki M, Kurachi T, Murata M, Kurachi M (1998): Expression of Fos protein in the limbic regions of the rat following haloperidol decanoate. Brain Res 791:125-136 